\title{
Information Infrastructures and the Future of Ecological Citizenship in the Anthropocene
}

\author{
Cagdas Dedeoglu ${ }^{1, *}$ and Cansu Ekmekcioglu ${ }^{2}$ \\ 1 The Center for Critical Research on Religion, Newton, MA 02458, USA \\ 2 Faculty of Information, University of Toronto, Toronto, ON M5S 3G6, Canada; \\ cansu.dedeoglu@mail.utoronto.ca \\ * Correspondence: dedeoglucagdas@gmail.com
}

Received: 1 October 2019; Accepted: 27 December 2019; Published: 5 January 2020

\begin{abstract}
In the last two decades, the concept of ecological citizenship has become a recurrent theme in both popular and academic discussions. Discussions around the prospects of, and limitations to, ecological citizenship have mostly focused on the idea of political agency and the civic responsibility of individuals in relation to their environments, with an emphasis on environmental justice and sustainability. However, the current scholarship has yet to adequately characterize its conceptual bases and empirical applications from an information perspective. Therefore, this paper provides an overview of citizenship studies and infrastructure studies for developing more nuanced understanding(s) of epistemological models for ecological citizenship in our networked world. Drawing on the literature on information infrastructure, this paper then proposes a conceptual framework to understand ecological citizenship as constituted both discursively and techno-materially through neoliberal, anthropocentric informational infrastructures.
\end{abstract}

Keywords: Anthropocene; ecological citizenship; information infrastructure; infrastructural imagination; knowledge production; neoliberalism; Pauline ideal

\section{Introduction}

The modern human experience has shown itself to yield both socio-economic inequalities and socio-ecological ones, such as plastic pollution, biodiversity loss, and climate change. Scientists say that human activities have caused the sixth mass extinction of species, which is beyond dispute the most devastating one for the biota (Ceballos et al. 2015). Humanity has destroyed 60 percent of the animal population since the 1970s (Carrington 2018). The world is warming. According to recent reports, even if the parties of the Paris Agreement keep their promises, this will not be enough to stop the warming trend (UNEP 2017; IPCC 2018). Welcome to the Anthropocene. This term, as a geological concept, characterizes a new period in which "the global effects of human activities have become clearly noticeable" (Crutzen and Stoermer 2000, p. 17). These activities have been continuing since the second half of the 18th century and their outcomes are evident in the above examples.

Scholars have responded to the Anthropocene, without necessarily mentioning it, in different ways. They challenge the ongoing economic systems (Brown and Timmerman 2015; Akbulut et al. 2019) and corporate business models (Crane et al. 2008) or investigate the political (Paterson 2001; Latour 2004; Chandler 2018), legal (Stone 1972; Delaney 2003), geographical (Lorimer 2012), ethical (Kopnina et al. 2018), philosophical (Haraway 2015; Ferrando 2016; Braidotti 2018), and religious (Taylor 2001a, 2001b) implications of human experience in the Anthropocene. Others direct their attention towards value formation, assuming that individuals have different perceptions and judgments of (ecological) reality (Díaz et al. 2015; Tengö et al. 2014; Pascual et al. 2017). Some scholars have focused on the actual practices of alternative socio-material movements at grassroots levels (Schlosberg and Coles 
2016; Burke and Stephens 2018; Islar and Irgil 2018; Temper et al. 2018). Finally, there are essential studies that offer in-depth examinations of environmental and ecological forms of citizenship (Reid and Taylor 2000; Dobson 2003; Valencia Sáiz 2005; Hayward 2006; MacGregor 2006; Crane et al. 2008; Smith and Pangsapa 2008; Humphreys 2009; Mason 2009). Most of them are interdisciplinary, yet some themes come to the fore.

Drawing on the above-mentioned research, this study considers ecological citizenship as a response to the Anthropocene. In this sense, we agree with the works emphasizing the importance and potential of ecological citizenship. We also assert that the actualization of ecological citizenship depends on infrastructural compatibility. In this paper, we mainly concentrate on information infrastructures since ecological citizenship is very much related to individuals' knowledge about and comprehension of their environments. In other words, we focus on the information infrastructure on which ecological citizenship performs - or rather cannot perform so well—as we think of an infrastructural connection between individuals and their framing of environments. Therefore, the main question we would like to answer in this article is as follows: what does the concept of information infrastructure offer for the understanding of ecological citizenship? By answering this question, we aim to show how we happen to "know" about citizenships and the environments, based on the current information infrastructures, and discuss the implications of these forms of "knowing" for ecological citizenship in the Anthropocene.

Infrastructure has recently gained much prominence in different fields, such as Science and Technology Studies (STS), anthropology, and political science. Following the pioneering studies of Susan Leigh Star and Geoffrey Bowker (Star and Griesemer 1989; Star and Ruhleder 1996; Bowker and Star 1999; Bowker 2000), vital infrastructure-related studies have also appeared in the broader areas of environmental science and humanities (Miller and Edwards 2001; Edwards 2010; Goodman et al. 2016; Blok et al. 2016; Richardson 2016; Schick and Winthereik 2016; Asdal and Hobæk 2016; Harvey 2017; Bridge et al. 2018; Hetherington 2019; Chester et al. 2019). These studies concentrate on physical infrastructures, such as energy, transportation, and waste management or information-related ones and cyberinfrastructures. To the best of our knowledge, there is no work focusing on the relationship between citizenship and the environment from an information infrastructure perspective. In this respect, our purpose is to extend the vision of Star and Bowker and other infrastructure scholars to approach ecological citizenship from an information infrastructure perspective. Moreover, we consider this attempt, regardless of the ecological consequences it may have, as contributing to ongoing debates on citizenships and the study of non-citizens.

\section{Citizenship Studies and Ecological Citizenship}

This section is devoted to a brief account of research which has occupied the field of citizenship studies as well as to the manifestations of ecological citizenship in the literature. In doing so, we aim to show the necessity of an information infrastructural approach to the study of ecological citizenship. Our investigation begins with a brief review of citizenship studies, together with an analysis of the concept of the citizenship. It then concentrates on the current debate on ecological citizenship.

\subsection{A Brief History of Citizenship (and the Study of It)}

Citizenship, as both an idea and a form of practice, has developed within various historical, philosophical, and cultural contexts. Although the term of citizen has been used as a right-based status in the (political) community since ancient times (Heater 2004), specific historical developments have affected the way it is understood and practiced. According to Isin and Turner (2007), these developments include the English civil war, the American War of Independence, and the French Revolution. Moreover, Hindess (2002) attributes importance to the emergence of the Westphalian order and its spread through the European imperial conquest. We would add the Industrial Revolution to this list as it has yielded substantial structural changes for the modern world system. A political economy of citizenship will also contain the histories of imperialism and colonialism, techno-capitalism, globalization, and finally, 
neoliberal governance. As an outcome of all these historicities, the transformation of citizenship (in industrialized states) has occurred in three dimensions: status, rights, and identity (Joppke 2007). First, the ethnic pluralization of the citizenry and the liberalization of access to citizenship have changed the status of citizenship. Parallel to this has been the shift from social rights to minority rights. Finally, the (neo)liberalization of access to citizenship and the rise of minority rights have brought pressure on states in seeking new forms of unity and integration.

Citizenship, which was originally approached by legal and normative political theories, has later become a subject of inquiry in sociological circles. Marshall's (1950) conceptual framework of social citizenship has inspired various academic and policy works. He portrayed citizenship as a collection of civil, political, and social rights, and emphasized the state responsibility to guarantee the fulfillment of these rights. This argument was in line with the vision of the UN Declaration of Human Rights that has made a case for the universal right to citizenship (Hindess 2002, p. 138). Thus, modern understanding of citizenship has evolved under 'modern necessities' of "work, public service (for example, military or jury service), and parenthood or family formation" (Isin and Turner 2007, p. 5).

After the 1990s, however, scholars have treated citizenship and state-society relations in multiple ways. Two contrary views have become prominent: Brubaker's (1992) Weberian social closure approach that considers citizenship as a top status and Soysal's (1994) post-Marshallian focus on the changes about citizenship under globalization. In other words, modern citizenship that was initially described as membership to a political community, namely the nation of the state in the post-Westphalian order, was challenged by the critiques of the Marshallian vision. Ethnic, religious, and gender-related concerns have occupied center stage in these critiques. In the last two decades, journals such as Citizenship Studies have provided the impetus for alternative theorizations of citizenship. As a result, the studies on citizenship have expanded to reflect the themes of "migration, religion, education, militarism, indigenous struggles, ecological politics, social justice, surveillance, deportation" (Nyers 2007, p. 2) and enriched with empirical data. Thus, the understanding of citizen and the practices of citizenship have transformed. This transformation has been twofold. Vertically, the unit of analysis has moved away from the state and the studies have concentrated on individuals and groups as well as international institutions. Horizontally, the focus has varied to incorporate new areas of inquiry. Eventually, the literature on citizenship has considerably diversified. For instance, our analysis of the articles published in Citizenship Studies between 1997 and 2019 showed that at least 40 distinct conceptualizations of citizenship have been made thus far. ${ }^{1}$ Here, the question is whether ecological citizenship will remain one of those rarely visited conceptualizations or have a central position in the discourses of political societies.

\subsection{Green Citizenships: Environmental or Ecological?}

Scholars of citizenship have been dealing with ecological issues for at least the last three decades. Gabrielson (2008), in her review of the scholarly efforts concerning green citizenship, informs the reader that van Steenbergen (1994) gave an early example of integrating the two groups of studies, the one that concentrates on the issues related to citizenship and the other that deals with the ecological problems. Having not been satisfied with the current level of scholarship about green citizenship, Gabrielson presents a comparison of liberal and republican accounts of green citizenship and points to the necessity of a more comprehensive theorization of green citizenship. Since citizenship studies mostly depart from

1 They include but are not limited to liberal citizenship, republican citizenship, economic citizenship, ethnic citizenship, inclusive citizenship, differentiated citizenship, biometric citizenship, educated citizenship, gay citizenship, green citizenship, global citizenship, non-citizenship, cultural citizenship, silent citizenship, digital citizenship, post-citizenship, stakeholder citizenship, sexual citizenship, multi-layered citizenship, mobilizational citizenship, extraterritorial citizenship, affective citizenship, ecomodernist citizenship, effective citizenship, care-tizenship, quasi-citizenship, social citizenship, local citizenship, imperial citizenship, urban citizenship, active citizenship, rhetorical citizenship, entrepreneurial citizenship, fragmented citizenship, aesthetic citizenship, deliberative citizenship, neoliberal authoritarian citizenship, dual citizenship, sustainable citizenship, and cosmopolitan citizenship. 
liberal or civic republican bases, green citizenship is also framed through these accounts. Among these two frameworks, while liberal approach prioritizes individual rights, civic republicanism prefers to focus on the notion of common good. Therefore, "unlike the more radical green approaches, the liberal model seeks to avoid the tendency to assert sustainability as the exclusive end of citizenship because of its commitment to value pluralism" (Gabrielson 2008, p. 431). On the other hand, "the recent revival of the civic republican tradition has brought to the fore an understanding of citizenship that emphasizes virtue, duty, self-governance, and community" (ibid., p. 433).

Both the liberal emphasis on the pluralism of rights and the civic republican emphasis on common good support the attempts for the greening of citizenship in some respects. However, these efforts remain limited, considering the socio-ecological and political-economic realities of the Anthropocene. In line with other scholars (Gilbert and Phillips 2003; Latta 2007), we think that these new realities, or rather, our recent awareness about them, suggest an urgency in reconceptualizing citizenship, instead of the greening of it. For us, this urgency also means that we need to go beyond the use of "environmental or ecological citizenship" and be clear and precise about where each of the two conceptualizations of green citizenship stand.

Crane et al. (2008, pp. 373-74) identify three distinct approaches in the literature about ecological citizenship. The first approach is based on the Marshallian understanding of citizenship that emphasizes either individuals' right to environment (Shelton 1991) and the importance of a balance between intrinsic and instrumental values of the environment (Sagoff 1988). The second one is exemplified by Curtin $(1999,2003)$ who criticizes the dominant view of citizenship, having its roots in Western culture and state formation as well as colonialism. He instead argues for a citizenship model that does not exclude ecological communities from its moral trajectory. Lastly, Dobson (2003) offers a post-cosmopolitan, non-territorial version of ecological citizenship. This classification adequately explains several individual positions in respect to the relationship between citizenship and the environment.

However, such a broad understanding of ecological citizenship is unable to untangle the embedded anti-ecological implications of citizenship that is framed and supported by the nation-state system. We therefore adopt the concepts of environmental citizenship and ecological citizenship as defined by Dobson (2003) in Citizenship and the Environment. Accordingly, while the former "refers to attempts to extend the discourse and practice of rights-claiming into the environmental context" (Dobson 2003, p. 89). Within liberal or civic republican versions of citizenship, the latter is associated with an alternative understanding of citizenship. Under this definition, the anthropocentric works of Shelton and Sagoff stay out of the exemplary efforts towards ecological citizenship. How should we frame this alternative? In this article, we do not discuss the post-cosmopolitan nature of ecological citizenship as Dobson did. Instead, we argue that citizenship must have, first and foremost, an eco-centric value basis.

We agree with Dobson that the global scale impact of ecological problems force us to reconsider liberal and republican forms of citizenship. However, we disagree with Dobson's claim on the "difference between the community of citizens and the community of humanity" (Dobson 2003, p. 27). The lack of harmony between human rights and citizenship rights cannot be overcome without an alternative notion of community, including legal-political community. This alternative notion requires ecological citizenship to rely on a post-anthropocentric vision. This vision may help to ensure infrastructural compatibility of citizenship with the socio-ecological conditions of the Anthropocene. As Isin and Turner (2007, p. 12) imply, inalienable human rights and the rights of citizens may be reconciled to bring justice for all. Thus, this study is positioned between Curtin's critical eco-communitarianism and Dobson's post-cosmopolitanism. We are in line with Curtin in the sense that ecological citizenship needs to be built upon "a global practice of localized care" (Curtin 1999, p. 16). More importantly, Curtin moves beyond the nature-culture distinction by criticizing Western attitudes towards the environment and other cultures. He gives examples of the loss of native languages in North America and Australia, and of tribes in Brazil (ibid., p. xi). These examples point how the loss of cultures, people, and biodiversity are closely related to each other. All of them are 
expressions of the same historical process, so does citizenship. This critique, therefore, brings us to the genealogy of citizenship.

As Hindess (2002, p. 129) noted, "romanticised images of the Greek polis and the Roman res publica have haunted Western social and political thought". Isin (2002) is one of a few experts who have challenged these images through a genealogy of citizenship based on the stories of outsiders and strangers. Moreover, in "Citizens without Nations", he investigates "genealogies of the relationships between state, nation, and community by Max Weber, Hannah Arendt, and Michel Foucault" (Isin 2012, p. 454). Isin draws our attention to the requirement for the deconstruction of the Pauline ideal lying at the roots of citizenship. Drawing on Weber's concern for consent and choice, Arendt's analysis of the conquest of the state by the nation, and Foucault's depiction of bourgeoisie as the nation, Isin emphasizes the importance of a genealogy of brotherhood and birthright citizenship. Isin's dialogue with Foucault enables us to reconsider general characteristics of citizenship today. In his analysis, Isin benefits from Foucault's distinction of disciplinary and regulatory powers. According to Foucault (2003), disciplinary mechanisms of power emerged in the 17th century and regulatory mechanisms appeared in the 18th century. While the former is utilized to discipline man-as-body, the latter is aimed at regulating (and controlling) man-as-species. It is not surprising that the emergence of regulatory mechanisms coincides with the Anthropocene. Further, the latest regulatory mechanisms such as ecogovernmentality or environmentality (Agrawal 2005) work on neoliberal infrastructures. The Enlightenment, capitalism, modernity, mass consumerism, etc., can be blamed for today's ecological crisis (Chandler 2018, p. 7). However, an infrastructural imagination directs our attention to the importance of understanding ecological citizenship as a further deconstruction of the Pauline ideal, as a critique of not just brotherhood and birthright citizenship but also personhood and anthropocentrism of citizenship. Such a deconstruction of the Pauline ideal will at the same time be an intervention from an information infrastructural perspective. Keeping in mind that "citizenship may be present in a state without yet being fully developed among its inhabitants" (Hindess 2002, p. 138), an information infrastructural approach may help us to understand the ways of the development of ecological citizenship among all inhabitants.

\section{Information Infrastructures and the Formation of Knowledge}

According to Oxford English Dictionary (Lexico n.d.), infrastructure means "[t]he basic physical and organizational structures and facilities (e.g., buildings, roads, power supplies) needed for the operation of a society or enterprise". In this definition, infra-infers "below" and infrastructure stands for the "underlying structure". The word first emerged as an engineering concept in French and came to English in 1927. Its initial arrival in English was associated with the appearance of some other transportation terms such as "garage (1902), limousine (1902), metro (1904), marque (a make of car, 1906), and couchette (railroad car with sleeper berths, 1920)" (Schultz 2012 cited in Carse 2017, p. 30). Such a modern emphasis on physical structures has reflected the term's mainstream usage in English. Later, French structuralists such as Saussure, Levi-Strauss, and Althusser employed the term to explain deep structural relations (Carse 2017, p. 35). Infrastructure has both manifested modern imagination and played a role in the formation of the modern realm. Its emergence and development have taken place within conceptualizations of the French modernism and structuralism. Finally, the STS scholars and anthropologists who move away from the modernist and structuralist epistemologies have re-introduced the concept to explain complex societal systems, including information and communication systems.

In the 1990s, the concept of infrastructure started to become popular in information studies. Although a singular definition of information infrastructure is almost impossible (Mongili and Pellegrino 2014, p. xxi), Star and Ruhleder (1996) developed a conceptual approach that applies to both physical and information infrastructures. Under this approach, infrastructure has the following components as adapted from Star and Ruhleder (1996, p. 113): 
1. Embeddedness. Infrastructure is 'sunk' into, inside of, other structures, social arrangements and technologies.

2. Transparency. Infrastructure is transparent to use, in the sense that it does not have to be reinvented each time or assembled for each task, but invisibly supports those tasks.

3. Reach or scope. This may be either spatial or temporal-infrastructure has reach beyond a single event or one-site practice.

4. Learned as part of membership. The taken-for-grantedness of artifacts and organizational arrangements is a sine qua non of membership in a community of practice ... Strangers and outsiders encounter infrastructure as a target object to be learned about. New participants acquire a naturalized familiarity with its objects as they become members.

5. Links with conventions of practice. Infrastructure both shapes and is shaped by the conventions of a community of practice, e.g., the ways that cycles of day-night work are affected by and affect electrical power rates and needs.

6. Embodiment of standards. Modified by scope and often by conflicting conventions, infrastructure takes on transparency by plugging into other infrastructures and tools in a standardized fashion.

7. Built on an installed base. Infrastructure ... wrestles with the "inertia of the installed base" and inherits strengths and limitations from that base.

8. Becomes visible upon breakdown. The normally invisible quality of working infrastructure becomes visible when it breaks; the server is down, the bridge washes out, there is a power blackout. Even when there are back-up mechanisms or procedures, their existence further highlights the now-visible infrastructure.

The alignment of these components generates an infrastructure and, therefore, has important implications for theories and practices of citizenship. Before examining these attributes in more detail, it is important to analyze information infrastructures from a comparative historical perspective. This will also reveal the relationship between information and knowledge in an infrastructural context.

In his comparative historical investigation of information infrastructures, Edwards (2010, p. 10) uses the large technical systems (LTS) approach (from a sociotechnical analysis perspective) and explains the infrastructure development through six general phases: invention; development and innovation; technology, growth, and competition; consolidation; splintering and fragmentation; and decline. Specifically, he emphasizes the role of system builder at the phases of invention, development, and innovation, and employs the example of Thomas Edison as a system builder. The Edison example indicates that the development of infrastructure, e.g., electric infrastructure, demands more than technical innovation and also necessitates the coming together of "organizational, economic, political, and legal" components. This complex development model gives infrastructures their unique characteristic: they cannot be designed or managed from above. However, this does not mean that consolidation can be easily achieved. An infrastructure development always produces winners and losers, for example, digital versus printed media (Edwards 2010, p. 12).

The growth of the Internet as an infrastructure (Sandvig 2013; Rasmussen 2014; Plantin et al. 2018) deserves a closer look for two reasons. First, it is one of the most critical infrastructural changes as it scaffolds the development of cyberinfrastructures. The game-changing role, which was played by electric infrastructure at the beginning of the 20th century, has been taken over by the Internet. It has followed Edwards' general phases of infrastructure development. Moreover, it has its own Thomas Edisons (e.g., Vint Cerf, Robert Kahn, and Tim Berners-Lee). Secondly, the precipitous expansion of the Internet has generated an information revolution of exceptional scale, enabled new forms of knowledge formation, and thus, it complicated the relationship between knowledge and information (and data). As Siskin (2016) neatly shows, modern knowledge formation has relied upon both the cosmic systems (such as the Newtonian one) and worldly infrastructures (such as print in Britain). Hence, the infrastructural connection was once determined by the Enlightenment systems as Bacon's advancement of learning with its focus on organizations and management of knowledge reminds us 
(Siskin 2016, p. 6). Keeping in mind that the system is not infrastructure (Edwards 2010; Siskin 2016), we contend that today's knowledge formation is not as systematic as it was. It is chaotic and dispersed, and it relies upon diverse information infrastructures.

So, what is information infrastructure? Following Leigh Star's multidimensional relational understanding of infrastructure, Bowker et al. (2010) define information infrastructure as everything that makes knowledge work possible. That means that an infrastructural approach to knowledge must take into consideration materials, technologies, organizations, and individuals, including users. Therefore, a current list of information infrastructures includes, but is not limited to education and research institutions, libraries, museums, publishing houses, digital media platforms, legal-administrative bodies, contents, and the individuals that engage with and through them. Information infrastructures are associated with complex interactions among multiple stakeholders. Initial studies by Nadia Caidi $^{2}$ acknowledge that information infrastructures are products of "shared assumptions, diverging perspectives, and conflicting meanings attributed to them by actors who have a stake in their development" (Caidi 2004, p. 25). The emphasis on actors supports our claim that knowledge formation has become less systematic yet more infrastructural. The generally accepted view of knowledge and information exchange says that the boundary between information and knowledge might be vague for the generator of knowledge, but it is quite clear for the receiver, and "[r]eceiving information is in many cases not equivalent with gaining knowledge" (Meusburger 2016, pp. 33-34). However, for example, the Internet infrastructure has increased users' role as information infrastructures. In this respect, users are not mere receivers of the message; at the same time, they produce new information that is received as the sources of knowledge by other users. The sociotechnical changes that have been happening at the backdrop for more than 200 years, which consists 'the long now' of current infrastructures (Jackson et al. 2007), have transformed conventional types of users of knowledge into today's 'men of letters' 3 who are compelled to seek information under specific '-logos' (Bowker et al. 2010, pp. 103-4), but barely produce systematic knowledge.

The efforts to understand those sociotechnical changes are still ongoing. For instance, a workshop was organized in the UCLA's Center for Knowledge Infrastructures in 2013. While the workshop (and the Center) preferred to use the term knowledge infrastructure ${ }^{4}$ instead of information infrastructure, the main questions highlighted were essential and highly relevant to our discussion (Borgman et al. 2013):

- How are knowledge infrastructures changing?

- How do knowledge infrastructures reinforce or redistribute authority, influence, and power?

- How can we best study, know, and imagine today's (and tomorrow's) knowledge infrastructures?

The authors of this report addressed these questions to analyze the changing character of intellectual frameworks and research challenges. We believe that those intellectual frameworks shape not only academic, but also popular discourses-even the lack of intellectual framework determines them. Although our aim, in this paper, is not to answer the aforementioned questions, we want to emphasize the importance of asking them regarding citizenship. As the workshop report indicates, knowledge infrastructures are changing due to the changes in the meaning of knowledge, its mobilization, disciplinary boundaries, publication practices, spatiotemporal scales, and standards.

2 For a detailed discussion on the role of libraries as social actors in the development of national information infrastructures in four countries of Central and Eastern Europe, please see (Caidi 2001a).

3 Today's 'men of letters' are, for instance, Twitter users that can disseminate (mis)information very quickly and result in potential knowledge formations for other users.

4 As it is mentioned in the workshop report, the participants decided to avoid a discussion on terminology. But one of the participants has made a definition elsewhere (Edwards 2010, p. 17). According to this definition, the term of knowledge infrastructure focuses on the dimensions of people, artifacts, and institutions in respect to the production, sharing, and maintenance of knowledge. Therefore, the main difference between knowledge infrastructure and information infrastructure appears to stem from the varying ideas about information and knowledge. Yet, no consensus has been achieved on the terminology. 
It is assumed that infrastructures effectively support the relationship between information, knowledge, and action. Indeed, both knowledge infrastructures and the infrastructural changes are not exempt from power dynamics. Thus, this brings us to the second question about hierarchies. The choices between "medical research to women's vs. men's cancers, or diseases of the rich vs. diseases of the poor ... 'charismatic megafauna' (e.g., cuddly pandas or expressive, humanlike chimps) vs. other biota (e.g., blue green algae)" (ibid., p. 14) are made within the relations of power, and therefore, not exempt from hierarchies shaped through socio-political and economic norms and standards. Finally, the infrastructural nature of modern knowledge requires effective ways of studying them. Equally important is to find the ways of looking citizenship from an infrastructural imagination (Bowker 2014) to understand information and knowledge circulations throughout the history and among different communities as the articulations of competing value systems (Caidi 2001b). As citizenship is based on normative systematic knowledges of the past, an infrastructural imagination can contribute to study the ecological alternative supported by inclusively systematic knowledges.

\section{Discussion}

In this section, we try to imagine ecological citizenship and infrastructure together, with a specific emphasis on information infrastructure. Therefore, we will further discuss the general characteristics of current information infrastructures that both the idea and practices of citizenship build upon. In this way, we intend to explore challenges and promises of ecological citizenship in the age of neoliberal Anthropogenic information infrastructures.

\subsection{Looking at Ecological Citizenship from an Information Infrastructure Perspective}

In A Vast Machine, Paul N. Edwards questions the place of politics in the climate-related knowledge infrastructure and answers "everywhere" (Edwards 2010, p. xviii). In the same vein, we deal with ecological citizenship as a legal-political concept and its potential as a status. Therefore, our questioning has so far been an ecological version of what Isin (2012, p. 465) does when making a case for "a genealogy of fraternity and the deconstruction of the Pauline ideal" — the hegemonic ideal of the community (and citizenship), which is based on an exclusive brotherhood proposed initially by St. Paul. This study thus considers the adoption of ecological citizenship as a response to the information infrastructures generated through the Pauline ideal of state and citizenship. We therefore adapt Star and Ruhleder's eight components of infrastructure to see citizenship from an information infrastructure angle:

1. Embeddedness. Information infrastructures that are embedded in various artifacts, social agreements, and tools determine the forms of, and negotiations about, citizenship. Thus, typical historical accounts of citizenship (Isin and Turner 2007) may be analyzed from an information infrastructure perspective. Such an analysis would, for instance, show the effect of Enlightenment thought on the idea of citizenship (Curtin 2003) with a particular focus on knowledge production through an interplay between church, state, and universities.

2. Transparency. Information infrastructures are transparent to use and invisibly support individual enjoyment of citizenship rights and fulfillment of duties. Star et al. (1997) argued that transparency goes hand in hand with membership. This means that citizenship information must be equally accessible to everybody as members of a political community. Focusing on what remains transparent is, therefore, important for developing a comprehensive approach to citizenship. The question of transparency also enables us to further problematize the notion of inclusion: who "deserves" to be a citizen and who does not.

3. Reach and scope. Information infrastructures perform beyond "single event or local practice" (Star and Ruhleder 1996, p. 113) and this general characteristic is compatible with the state-level implementation of citizenship acts. Moreover, globalization has dramatically influenced the reach and scope of information infrastructures in the sense that different forms of citizenship interact with each other all around the world. 
4. Learned as a part of membership. Information infrastructures are learned, or instead taught, within a communal context. This is also the way one learns about citizenship through information infrastructures. For example, local libraries provide intersubjective spaces that enable new immigrants to perform citizenship.

5. Links with the conventions of practice. Information infrastructures both affect and are affected by citizenship practices. The mutual development of the Internet and new acts of citizenship, such as feminist protests, may be a good example of these links. The active, developing, open, and innovative features of grassroots citizenship may be seen, in this respect, as potential factors shaping the future of citizenship. However, information infrastructures are still designed from a human-centric perspective and posthuman voices are not yet strong enough to transform these infrastructures. For example, animal rights advocacy has been largely marginalized in public discussions around citizenship issues.

6. Embodiment of standards. Invisible infrastructures become transparent in their interactions with each other. Individuals' experience of the standards that emerge when the information infrastructure becomes transparent will determine the quality of their citizenship experience. This maybe constitutes the most crucial dimension of an information infrastructure in its relationship with citizenship because "one person's well-fitting standard may be another's impossible nightmare" (Star and Lampland 2009, p. 5). The literature on citizenship and the environment shows how standardization excludes various ecological communities at different scales.

7. Built on an installed base. Any infrastructure is dependent on its installed base, and for information infrastructure, this also includes the knowledge base. In this sense, citizenship cannot perform appropriately on information infrastructures that are based on incorrect knowledge bases. Minority movements, for example, can be also understood as infrastructural movements since they aim to struggle against the installed knowledge base that is established through modern nation-state experience. In a similar vein, traditional understandings of citizenship cannot efficiently respond to socio-ecological problems that exceed national borders.

8. Becomes visible upon breakdown. Information infrastructures supporting the practices of citizenship become visible when they do not function well. Examples include e-government applications or the protests targeting the (neo)liberalization of higher education systems.

Infrastructures are mostly considered to be indispensable. "To be modern is to live within and by means of infrastructures" (Edwards 2010, p. 8). That means that if individuals are accustomed to enjoying "reliable, standardized, and widely accessible" systems and services, infrastructures make this possible. However, we seldomly think about their importance for modern societies and these rare moments are very much dependent on the infrastructure's malfunctioning. Infrastructure-related activities such as construction, monitoring, and maintenance all have a place in the management of modern life. Take, for example, the construction, monitoring, and maintenance of roads. These are regular activities and they enable transportation systems to function properly and to reduce the risk of accidents. These activities can be performed by state agencies, private companies, or public-private consortiums according to types of governance.

While the roads constitute physical infrastructures, the knowledge about their construction, monitoring, and maintenance is contingent on information infrastructures. Moreover, the decisions of what to construct and how to construct, and the idea of construction itself, are framed within specific paradigms produced through information infrastructures. The transportation system fails if roads are not constructed, monitored, and maintained successfully. In addition, if the construction plan does not have ecological validity, the transportation system fails in ecological terms. Such a failure leads to protests, but this does not reverse biodiversity loss. Thus, the need for precautionary action is evident and urgent. A contrary example is that the width of a street as a physical infrastructure affects the success of protests. The construction of that street is a byproduct of information infrastructures 
producing knowledge about construction and architecture. ${ }^{5}$ In the next section, we will expand more on this aspect by focusing on the relationship between information infrastructures, individuals, and their environments with respect to the concept of ecological citizenship.

\subsection{The Anthropocene, Neoliberal Information Infrastructuring and the Future of Ecological Citizenship}

Homo sapiens have been transforming Earth's ecosystems at least since the late Pleistocene (30,000-100,000 BP). The transformation intensified with the Neolithic revolution (9500 BP), further presented an anthropogenic character through domestication of plants and animals (3000 BP), increased incrementally during the colonial era, and dramatically affected the metabolisms of societies since the industrial revolution and particularly during the techno-capitalist era (Taylor et al. 2019). The development of current information infrastructures has accompanied the last phase of this transformation, namely the Anthropocene, with an approximately 200 years of 'the long now' (Bowker et al. 2010, p. 103). This means the origins of current information infrastructures coincide with the rise of industrial capitalism. Moreover, neoliberal governance has been determining the dynamic nature of anthropogenic infrastructuring ${ }^{6}$ in the last couple of decades. In other words, neoliberal anthropogenic infrastructuring constitutes the basis of the interactions between individuals and their environments in our time.

The Anthropocene, in addition to its geological meaning, has recently gained a metaphysical meaning. This emphasizes the need for a philosophical, ontological turn in human perception of reality to prevent devastating consequences of human activities. According to the Enlightenment philosopher Helvétius (1799, p. 28), "reason is nature modified by experience". If Helvétius lived today, he would possibly define the Anthropocene as the outcome of the cognitive dissonance between reason and nature. In other words, he would think that modern human experience has produced the dissociation between 'rational' human beings and their 'environments', outcomes of which we discuss in this study. Therefore, if the Anthropocene is a break with modernity, as Bruno Latour thinks, then it contains the solution in itself: a reintegration of reason and nature. However, this nature is different from the "Nature of olden days" (Latour 2015, p. 28). Discussing the Gaia hypothesis in respect to the Anthropocene, Latour states that the Anthropocene epoch has shaped both human being and nature, and therefore, Lovelock's (2000) Gaia is unlike nature as we know it. Thus, Gaia is the nature modified by human experience. The opposite is equally accurate: Human experience is modified within this nature, too. Moreover, we need to think of this relationship under the critiques of the Anthropocene. As Hetherington (2019, p. 3) summarizes, the well known critiques center around three themes: Haraway's (2015) nonhuman account, Todd's (2015) claim that the term Anthropocene hides the colonial and capitalist power dynamics, and Swyngedouw's (2010) examination of the concept as an issue leading to "political paralysis". The metaphysical possibilities of the Anthropocene may continue to expand through the inclusion of similar critiques.

With this, the Anthropocene, as a general characteristic of information infrastructures, has at least two implications for the ecological citizenship. The Anthropocene epoch is both the reason and the result of the modern state mechanism, including the sub-mechanism of citizenship. Moreover, these accounts have always associated with human exceptionalism accompanied by (post)colonialism and prioritized the rights of some human groups. The outcome has been the Anthropocene. On the other hand, as we all are the children of the Anthropocene, we take the anthropogenic conditions for granted and act accordingly. Indeed, many people do not question these conditions. Despite

5 In this debate, "Haussmannization" of Paris in the mid-19th century deserves more attention. One of the main purposes of the urban renewal program initiated by the urban planner Baron Georges-Eugène Haussmann was to create a city that makes things difficult for revolutionary acts similar to those of previous decades.

6 Blok et al. (2016) edited a special issue of Science as Culture on infrastructures and the environment in which they made a shift from environmental infrastructures to "Infrastructuring Environments", following the advice of the Editor. We agree with this shift as infrastructuring meets, in a better way, the dynamic nature of human activities. 
the increased salience of diversity issues throughout the world, individuals are not open to radical solutions for sustaining diversity. This is so because diversity is itself a value-laden concept. Even the words diversity and worth (to have a value) are etymologically intertwined as will be shown in the following paragraph.

Bowker's emphasis on "taking diversity as a 'measure of information in a hierarchical classification'" (Bowker 2000, p. 670) led us to question the etymological connections between diversity and worth. Such a connection may be helpful to understand information infrastructures of states and global society. Diversity originates from Latin divertere or dis + vertere (to turn in opposite directions). Similarly, worth comes from weorthan in Old English, which approximates vertere in Latin and even vartate in Sanskrit. That means that diversity and worth have common etymological roots. Thus, "taking diversity as a "measure of information in a hierarchical classification'" reminds us that every diversity contains a value-based hierarchy. Hence, the etymological association of diversity and worth accommodates a holistic meaning: the rule (-archy/-archos from hierarchy) of 'turn'ing things to be 'worth'while. Such a definition allows us to see hierarchies in the diversity and diversities in the hierarchy. This complexity is what humans have created thus far. Moreover, this emphasizes the interrelatedness of diversity and hierarchy in infrastructures while deciphering the connections between citizenship and information infrastructures. Such a value-oriented, human exceptionalism may eventually prevent the development of multidimensional, relational thinking beyond the box under the information infrastructures embedded in educational and legal-administrative systems.

Concerning the educational component, we consider Dobson's idea of ecological citizenship education through public schools as a proposal related to information infrastructures. However, this can be criticized from at least two aspects. First, the idea of ecological citizenship education assumes that pro-environmental behavior at individual level, e.g., calculating carbon footprint and acting accordingly, would solve ecological problems. This assumption is unable to fully capture the role of state and market forces in the production of environmental knowledge. According to Lave (2012, p. 19) "the production of those [environmental knowledge] claims is a surprisingly central site of neoliberalization". Lave shows the impact of neoliberal science regimes on both academic and non-academic knowledge production. Under neoliberal science regimes, academic knowledge is mostly produced on the basis of not common good, but the market needs. Moreover, while the knowledge production outside the academy is open to the influence of practices such as local and indigenous attempts, citizen science, and crowdsourcing (ibid., p. 29), the regimes of truth are still dominated by state and market forces. Within these circumstances, ecological citizenship education should aim system-level changes and, therefore, keep a critical eye on science and knowledge production. Moreover, a related problematization regarding Dobson's idea of ecological citizenship education is that the loose connection between legal-administrative accounts of citizenship and socio-ecological realities in Dobson's formulation (Adler 2005) decreases the possibility of seeing it as a strong infrastructural intervention. As proved by many examples, e.g., the case Chile's Alto Bio Bio (Latta 2007) and the projects in Brazilian Amazonia (Ritter et al. 2017), environmental regulations, including environmental impact assessment, do not provide the efficient protection against anti-ecological actions. Therefore, an infrastructural imagination of ecological citizenship should also treat the problem of environmental regulations.

It is possible to trace the consequences of configurations in legal-administrative information infrastructures through different cases. For example, Asdal and Hobæk's (2016) ethnographic work demonstrates how regular parliamentary work (documents, expert reports, commission meetings, etc.) has historically infrastructured the whale issue and determined the fate of both whales' and humans' interaction with their environments in Norway. "The whale issue shows how a national parliament worked actively upon the questions, species and publics involved-rather than delegating nature-objects to scientific experts" (Asdal and Hobæk 2016, p. 113). In a similar vein, Stoa (2015) asserts that the US approach to environmental lawmaking and natural resource management is a result of the anthropogenic attitudes, but not suitable for responding to ecological conditions such as 
droughts, floods, and wildfires. In this sense, the anthropogenic nature of lawmaking does not allow the development of resilient communities but support the emergence of 'post-disaster' institutions, such as insurance companies. Therefore, there is a diversity-hierarchy situation here. Some interests are seen as superior to others, and institutionalization occurs along a continuum of normative practices.

The example about the US lawmaking also supports the emphasis on neoliberalism as a more recent characteristic of information infrastructures. Neoliberalism is frequently depicted as a package of social and economic policies that arose as a reaction to globalization (Brown 2003). This reaction demands a smaller welfare state, the commodification of public goods, and free-market conditions. Nevertheless, neoliberalism has gone beyond market (Brown 2003) and regulated infrastructures of society (or rather deregulated) by reducing citizens to clients and "by making every citizen an agent of his or her own destiny" (Ong 2006, p. 2). Ong (2006) indicates that exceptions to neoliberalism can both preserve welfare benefits for citizens (e.g., subsidized housing in Russia) and exclude noncitizens from the benefits of capitalist development (e.g., the conditions of migrant workers in the Southeast Asia). Following scholars such as Karl Polanyi, we would also add that the neoliberal understanding of citizen ignores not only the rights of non-citizens, but also of citizens with less income as well as nonhumans. In this respect, both neoliberal governance and exceptions to it, in their own ways, have been transforming individuals and their environments.

Lastly, neoliberal information infrastructures present an opportunity for entrepreneurs to turn the issues of identity politics into profitable products and services that compete in the market (Caputo 2009, p. 6). But those issues remain unsolved. This also is true for ecological identities as they can only be practiced by some individuals. Individuals do not act as responsible citizens but as customers with different consumer behaviors. Thus, we think that Dobson $(2003$, p. 8$)$ is right in arguing that ecological citizens will have a greater positive impact on democracies than consumer environmentalism does. However, the practices of ecological citizenship are constrained by capitalist needs of destruction (Badiou 2009, p. 27) and neoliberal market conditions reproduced and delivered through current information infrastructures. Under these circumstances, ecological citizenship is, at best, defined as an identity among others with a market value. Eventually, individuals show contradictory identities, on the one hand they recycle their waste as their everyday life practice but on the other hand they continue to work for a company leaving a huge carbon footprint on the earth systems.

\section{Conclusions}

In this article, we developed an information infrastructure framework to analyze ecological citizenship. We examined the nature of, and the changes in, information infrastructures and imagined citizenship as an infrastructural theme. We began our investigation by asking what citizenship studies might expect from an infrastructural imagination and especially from the concept of information infrastructure. After engaging with two broad literatures of citizenship studies and information infrastructure, we suggested two possible answers. One, citizenship, as a form of knowledge, always depends on specific information infrastructures. Two, citizenship practices, directly and indirectly, build upon these information infrastructures. In this sense, ecological citizenship directly depends on information infrastructures because of the relationship between knowledge and action. Citizenship information flowing through information infrastructures helps people produce their own 'knowledge' about citizenship. Citizenship practices indirectly rely upon physical infrastructures, those of which are an outcome of information infrastructures.

Information infrastructures, such as universities, museums, libraries, Internet platforms, city councils, parliaments, contents, and people, determine the knowledge about what constitutes citizenship. The practices of citizenship determine whether citizens and noncitizens as well as humans and nonhumans co-exist or not. Thus, infrastructural imagination offers a valuable approach to the development of common, broadly available systems and services frequently delivered or controlled by governments in the public interest. Additionally, the idea of ecological citizenship captures how 
communication and expression are, to some extent, enabled by the hegemonic conceptualizations and practices of citizenship, and its implications for the neoliberal Anthropocene.

The Anthropocene demands an ecological infrastructural imagination supported by an eco-centric vision. Today's infrastructural arrangements will shape the future. The pressing ecological problems compel us to employ ecological citizenship as a legal-political concept, which extends beyond identity politics. This legal-political configuration must be designed through an inclusive value formation. Although indigenous communities and scholars advocate these values, established scholarship does not take into account their opinions. Maybe it is time to reformulate Paul's famous statement ${ }^{7}$ as follows: there is human and nonhuman, there is religious and nonreligious, there is heterosexual and queer; for you are all citizens. In this way, ecological citizenship can be reimagined not only as an identity, but also as the legal-political status of all living beings. This study pointed out the information infrastructure dimension of such a reformulation. Developments such as an increasing awareness about local environmental practices and indigenous (scientific) knowledge, the digitization of education and the emergence of alternative mediums of knowledge mobilization, and the integration of digital citizenship and new forms of ecological movements can be seen as the ways of intervention in such a reformulation. Future research may, therefore, include and compare empirical evidence to measure the contribution of such practices to the changes in information infrastructures.

In summary, this study has shown that the limits of ecological citizenship today can be read as infrastructural limits. That means that both knowledge of citizenship and citizenship itself have historically been built upon anthropogenic information infrastructures, which have recently been transformed through neoliberalism. Secondly, this paper reveals how being an ecological citizen and being an eco-centric human are not the same. If citizenship is not based on an eco-centric mode of existence, the future of humanity will be doubtful. Therefore, the deconstruction of the Pauline ideal must be supported by a post-humanist and a post-anthropocentric vision.

Author Contributions: Conceptualization, C.D. and C.E.; Methodology, C.D. and C.E.; Resources, C.D. and C.E.; Writing-original draft, C.D. and C.E.; Writing-review \& editing, C.D. and C.E. All authors have read and agreed to the published version of the manuscript.

Funding: This research received no external funding.

Acknowledgments: The authors are indebted to the comments of two anonymous reviewers.

Conflicts of Interest: The authors declare no conflict of interest.

\section{References}

Adler, John. 2005. Citizenship and the Environment by Andrew Dobson. Journal of Environmental Law 17: 143-45. Agrawal, Arun. 2005. Environmentality: Technologies of Government and the Making of Subjects. Durham: Duke University Press. [CrossRef]

Akbulut, Bengi, Federico Demaria, Julien-François Gerber, and Joan Martínez-Alier. 2019. Who Promotes Sustainability? Five Theses on the Relationships between the Degrowth and the Environmental Justice Movements. Ecological Economics 165: 106418. [CrossRef]

Asdal, Kristin, and Bård Hobæk. 2016. Assembling the Whale: Parliaments in the Politics of Nature. Science as Culture 25: 96-116. [CrossRef]

Badiou, Alain. 2009. St. Paul, Founder of the Universal Subject. In St. Paul among the Philosophers. Edited by John D. Caputo and Linda Martin Alcoff. Indiana Series in the Philosophy of Religion; Bloomington: Indiana University Press, pp. 27-38.

Blok, Anders, Moe Nakazora, and Brit Ross Winthereik. 2016. Infrastructuring Environments. Science as Culture 25: 1-22. [CrossRef]

7 "There is neither Jew nor Greek, there is neither slave nor free, there is neither male nor female; for you are all one in Christ Jesus" (Galatians 3:28). 
Borgman, Christine L., Paul N. Edwards, Steven J. Jackson, Melissa K. Chalmers, Geoffrey C. Bowker, David Ribes, Matt Burton, and Scout Calvert. 2013. Knowledge Infrastructures: Intellectual Frameworks and Research Challenges. UCLA Publications. Available online: https://escholarship.org/uc/item/2mt6j2mh (accessed on 10 August 2019).

Bowker, Geoffrey C. 2000. Biodiversity Datadiversity. Social Studies of Science 30: 643-83. [CrossRef]

Bowker, Geoffrey C. 2014. Foreword. In Information Infrastructure(s): Boundaries, Ecologies, Multiplicity. Edited by Alessandro Mongili and Giuseppina Pellegrino. Newcastle: Cambridge Scholars Publishing, pp. xii-xiii.

Bowker, Geoffrey C., and Susan Leigh Star. 1999. Sorting Things Out: Classification and Its Consequences. Inside Technology. Cambridge: MIT Press.

Bowker, Geoffrey C., Karen Baker, Florence Millerand, and David Ribes. 2010. Toward Information Infrastructure Studies: Ways of Knowing in a Networked Environment. In International Handbook of Internet Research. Edited by Jeremy Hunsinger, Lisbeth Klastrup and Matthew Allen. Dordrecht: Springer, pp. 97-118.

Braidotti, Rosi. 2018. A Theoretical Framework for the Critical Posthumanities. Theory, Culture E Society 36: 026327641877148. [CrossRef]

Bridge, Gavin, Begüm Özkaynak, and Ethemcan Turhan. 2018. Energy Infrastructure and the Fate of the Nation: Introduction to Special Issue. Energy Research \& Social Science 41: 1-11. [CrossRef]

Brown, Wendy. 2003. Neo-Liberalism and the End of Liberal Democracy. Theory E Event, 7. [CrossRef]

Brown, Peter G., and Peter Timmerman, eds. 2015. Ecological Economics for the Anthropocene: An Emerging Paradigm. New York: Columbia University Press.

Brubaker, Rogers. 1992. Citizenship and Nationhood in France and Germany. Cambridge: Harvard University Press.

Burke, Matthew J., and Jennie C. Stephens. 2018. Political Power and Renewable Energy Futures: A Critical Review. Energy Research \& Social Science 35: 78-93. [CrossRef]

Caidi, Nadia. 2001a. The Information Infrastructure as a Discursive Space: A Case Study of the Library Community in Central and Eastern Europe. Ph.D. dissertation, Department of Information Studies, University of California, Los Angeles, CA, USA.

Caidi, Nadia. 2001b. Technology and Values: Lessons from Central and Eastern Europe. In Proceedings of the 1st ACM/IEEE-CS Joint Conference on Digital libraries (JCDL '01). New York: Association for Computing Machinery, pp. 176-77. [CrossRef]

Caidi, Nadia. 2004. National Information Infrastructures in Central and Eastern Europe: Perspectives from the Library Community. The Information Society 20: 25-38. [CrossRef]

Caputo, John D. 2009. Introduction-Postcards from Paul: Subtraction versus Grafting. In St. Paul among the Philosophers. Edited by John D. Caputo and Linda Martin Alcoff. Indiana Series in the Philosophy of Religion; Bloomington: Indiana University Press, pp. 1-23.

Carrington, Damian. 2018. Humanity Has Wiped out $60 \%$ of Animal Populations since 1970, Report Finds. The Guardian. October 30 Sec. Environment. Available online: https://www.theguardian.com/environment/2018/ oct/30/humanity-wiped-out-animals-since-1970-major-report-finds (accessed on 16 April 2019).

Carse, Ashley. 2017. Keyword: Infrastructure-How a Humble French Engineering Term Shaped the Modern World. In Infrastructures and Social Complexity-A Companion. Edited by Penny Harvey, Casper Bruun Jensen and Atsuro Morita. New York: Routledge, pp. 27-39.

Ceballos, Gerardo, Paul R. Ehrlich, Anthony D. Barnosky, Andrés García, Robert M. Pringle, and Todd M. Palmer. 2015. Accelerated Modern Human-Induced Species Losses: Entering the Sixth Mass Extinction. Science Advances 1: e1400253. [CrossRef]

Chandler, David. 2018. Ontopolitics in the Anthropocene: An Introduction to Mapping, Sensing and Hacking, 1st ed. Series: Critical Issues in Global Politics; Abingdon and New York: Routledge. [CrossRef]

Chester, Mikhail V., Samuel Markolf, and Braden Allenby. 2019. Infrastructure and the Environment in the Anthropocene. Journal of Industrial Ecology, 23. [CrossRef]

Crane, Andrew, Dirk Matten, and Jeremy Moon. 2008. Ecological Citizenship and the Corporation: Politicizing the New Corporate Environmentalism. Organization \& Environment 21: 371-89. [CrossRef]

Crutzen, Paul J., and Eugene F. Stoermer. 2000. The 'Anthropocene'. Global Change Newsletter 41: 17-18.

Curtin, Deane W. 1999. Chinnagounder's Challenge: The Question of Ecological Citizenship. Bloomington: Indiana University Press.

Curtin, Deane W. 2003. Ecological Citizenship. In Handbook of Citizenship Studies. Edited by Engin F. Isin and Bryan S. Turner. London, Thousand Oaks and New York: SAGE Publications, pp. 293-304. 
Delaney, David. 2003. Law and Nature. Cambridge Studies in Law and Society. Cambridge and New York: Cambridge University Press.

Díaz, Sandra, Sebsebe Demissew, Julia Carabias, Carlos Joly, Mark Lonsdale, Neville Ash, Anne Larigauderie, Jay Ram Adhikari, Salvatore Arico, András Báldi, and et al. 2015. The IPBES Conceptual Framework—Connecting Nature and People. Current Opinion in Environmental Sustainability 14: 1-16. [CrossRef]

Dobson, Andrew. 2003. Citizenship and the Environment. Oxford: Oxford University Press.

Edwards, Paul N. 2010. A Vast Machine: Computer Models, Climate Data, and the Politics of Global Warming. Cambridge: MIT Press.

Ferrando, Francesca. 2016. The Party of the Anthropocene Post-Humanism, Environmentalism and the PostAnthropocentric Paradigm Shift. Relations: Beyond Anthropocentrism 4: 159-74. [CrossRef]

Foucault, Michel. 2003. Society Must Be Defended: Lectures at the College de France, 1975-1976. Edited by Mauro Bertani and Alessandro Fontana. Translated by David Macey. New York: Picador.

Gabrielson, Teena. 2008. Green Citizenship: A Review and Critique. Citizenship Studies 12: 429-46. [CrossRef]

Gilbert, Liette, and Catherine Phillips. 2003. Practices of Urban Environmental Citizenships: Rights to the City and Rights to Nature in Toronto. Citizenship Studies 7: 313-30. [CrossRef]

Goodman, Michael K., Jo Littler, Dan Brockington, and Maxwell Boykoff. 2016. Spectacular Environmentalisms: Media, Knowledge and the Framing of Ecological Politics. Environmental Communication 10: 677-88. [CrossRef]

Haraway, Donna. 2015. Anthropocene, Capitalocene, Plantationocene, Chthulucene: Making Kin. Environmental Humanities 6: 159-65. [CrossRef]

Harvey, Penelope. 2017. Waste Futures: Infrastructures and Political Experimentation in Southern Peru. Ethnos 82: 672-89. [CrossRef]

Hayward, Tim. 2006. Ecological Citizenship: Justice, Rights and the Virtue of Resourcefulness. Environmental Politics 15: 435-46. [CrossRef]

Heater, Derek. 2004. A Brief History of Citizenship. New York: New York University Press.

Helvétius, Claude Adrien. 1799. The True Meaning of the System of Nature. Translated from the French of Helvetius. with Notes. Edinburgh: Gale ECCO.

Hetherington, Kregg. 2019. Introduction. Keywords of the Anthropocene. In Infrastructure, Environment, and the Life in the Anthropocene. Edited by Kregg Hetherington. Durham and London: Duke University Press, pp. 1-16.

Hindess, Barry. 2002. Neo-Liberal Citizenship. Citizenship Studies 6: 127-43. [CrossRef]

Humphreys, David. 2009. Environmental and Ecological Citizenship in Civil Society. The International Spectator 44: 171-83. [CrossRef]

IPCC. 2018. Global Warming of $1.5^{\circ} \mathrm{C}$. Switzerland: Intergovernmental Panel on Climate Change, Available online: http://www.ipcc.ch/report/sr15/ (accessed on 20 April 2019).

Isin, Engin F. 2002. Being Political: Genealogies of Citizenship. Minneapolis and London: University of Minnesota Press.

Isin, Engin F. 2012. Citizens without Nations. Environment and Planning D: Society and Space 30: 450-67. [CrossRef]

Isin, Engin F., and Bryan S. Turner. 2007. Investigating Citizenship: An Agenda for Citizenship Studies. Citizenship Studies 11: 5-17. [CrossRef]

Islar, Mine, and Ezgi Irgil. 2018. Grassroots Practices of Citizenship and Politicization in the Urban: The Case of Right to the City Initiatives in Barcelona. Citizenship Studies 22: 491-506. [CrossRef]

Jackson, Steven J., Paul N. Edwards, Geoffrey C. Bowker, and Cory P. Knobel. 2007. Understanding Infrastructure: History, Heuristics and Cyberinfrastructure Policy. First Monday, 12. [CrossRef]

Joppke, Christian. 2007. Transformation of Citizenship: Status, Rights, Identity. Citizenship Studies 11: 37-48. [CrossRef]

Kopnina, Helen, Haydn Washington, Joe Gray, and Bron Taylor. 2018. The Future of Conservation Debate: Defending Ecocentrism and the Nature Needs Half Movement. Biological Conservation 217: 140-48. [CrossRef]

Latour, Bruno. 2004. Politics of Nature: How to Bring the Sciences into Democracy. Cambridge: Harvard University Press.

Latour, Bruno. 2015. Waiting for Gaia. Composing the Common World through Art and Politics. In What Is Cosmopolitical Design? Edited by Albena Yaneva and Alejandro Zaera-Polo. Farnham: Ashgate, pp. 21-33. 
Latta, P. Alex. 2007. Citizenship and the Politics of Nature: The Case of Chile's Alto Bío Bío. Citizenship Studies 11: 229-46. [CrossRef]

Lave, Rebecca. 2012. Neoliberalism and the Production of Environmental Knowledge. Environment and Society, 3. [CrossRef]

Lexico. n.d. Infrastructure | Definition of Infrastructure by Lexico. Lexico Dictionaries | English. Available online: https://www.lexico.com/en/definition/infrastructure (accessed on 3 September 2019).

Lorimer, Jamie. 2012. Multinatural Geographies for the Anthropocene. Progress in Human Geography 36: 593-612. [CrossRef]

Lovelock, James. 2000. Gaia: A New Look at Life on Earth. Oxford: Oxford University Press.

MacGregor, Sherilyn. 2006. Beyond Mothering Earth: Ecological Citizenship and the Politics of Care. Vancouver and Toronto: UCB Press.

Marshall, T. H. 1950. Citizenship and Social Class and Other Essays. Cambridge: Cambridge University Press.

Mason, Andrew. 2009. Environmental Obligations and the Limits of Transnational Citizenship. Political Studies 57: 280-97. [CrossRef]

Meusburger, Peter. 2016. Spatial Mobility of Knowledge: Communicating Different Categories of Knowledge. In Mobilities of Knowledge. Edited by Heike Jöns, Michael Heffernan and Peter Meusburger. New York: Springer, pp. 23-50.

Miller, Clark A., and Paul N. Edwards, eds. 2001. Changing the Atmosphere: Expert Knowledge and Environmental Governance. Politics, Science, and the Environment. Cambridge: MIT Press.

Mongili, Alessandro, and Giuseppina Pellegrino. 2014. The Boundaries of Information Infrastructures: An Introduction. In Information Infrastructure(s): Boundaries, Ecologies, Multiplicity. Edited by Alessandro Mongili and Giuseppina Pellegrino. Newcastle: Cambridge Scholars Publishing, pp. xviii-xlvi.

Nyers, Peter. 2007. Introduction: Why Citizenship Studies. Citizenship Studies 11: 1-4. [CrossRef]

Ong, Aihwa. 2006. Neoliberalism as Exception: Mutations in Citizenship and Solidarity. Durham and London: Duke University Press.

Pascual, Unai, Patricia Balvanera, Sandra Díaz, György Pataki, Eva Roth, Marie Stenseke, Robert T Watson, Esra Başak Dessane, Mine Islar, Eszter Kelemen, and et al. 2017. Valuing Nature's Contributions to People: The IPBES Approach. Current Opinion in Environmental Sustainability 26-27: 7-16. [CrossRef]

Paterson, Matthew. 2001. Understanding Global Environmental Politics: Domination, Accumulation, Resistance. Basingstoke: Palgrave Macmillan.

Plantin, Jean-Christophe, Carl Lagoze, Paul N. Edwards, and Christian Sandvig. 2018. Infrastructure Studies Meet Platform Studies in the Age of Google and Facebook. New Media \& Society 20: 293-310. [CrossRef]

Rasmussen, Terje. 2014. Internet and the Political Public Sphere: The Internet and the Public Sphere. Sociology Compass 8: 1315-29. [CrossRef]

Reid, Herbert, and Betsy Taylor. 2000. Embodying Ecological Citizenship: Rethinking the Politics of Grassroots Globalization in the United States. Alternatives: Global, Local, Political 25: 439-66. [CrossRef]

Richardson, Tanya. 2016. Objecting (to) Infrastructure: Ecopolitics at the Ukrainian Ends of the Danube. Science as Culture 25: 69-95. [CrossRef]

Ritter, Camila D., Gabriel McCrate, R. Henrik Nilsson, Philip M. Fearnside, Ulrika Palme, and Alexandre Antonelli. 2017. Environmental Impact Assessment in Brazilian Amazonia: Challenges and Prospects to Assess Biodiversity. Biological Conservation 206: 161-68. [CrossRef]

Sagoff, Mark. 1988. The Economy of the Earth: Philosophy, Law and the Environment. Cambridge: Cambridge University Press.

Sandvig, Christian. 2013. The Internet as Infrastructure. In The Oxford Handbook of Internet Studies. Edited by William H. Dutton. Oxford: Oxford Handbooks Online. [CrossRef]

Schick, Lea, and Brit Ross Winthereik. 2016. Making Energy Infrastructure: Tactical Oscillations and Cosmopolitics. Science as Culture 25: 44-68. [CrossRef]

Schlosberg, David, and Romand Coles. 2016. The New Environmentalism of Everyday Life: Sustainability, Material Flows and Movements. Contemporary Political Theory 15: 160-81. [CrossRef]

Shelton, Dinah. 1991. Human Rights, Environmental Rights, and the Right to Environment. Stanford Journal of International Law 28: 103-38.

Siskin, Clifford. 2016. System: The Shaping of Modern Knowledge. Infrastructures. Cambridge: MIT Press. 
Smith, Mark J., and Piya Pangsapa. 2008. Environment and Citizenship: Integrating Justice, Responsibility, and Civic Engagement. London: Zed Books.

Soysal, Yasemin Nuhoğlu. 1994. Limits of Citizenship: Migrants and Postnational Membership in Europe. Chicago: University of Chicago.

Star, Susan Leigh, and James R. Griesemer. 1989. Institutional Ecology, 'Translations' and Boundary Objects: Amateurs and Professionals in Berkeley's Museum of Vertebrate Zoology, 1907-1939. Social Studies of Science 19: 387-420. [CrossRef]

Star, Susan Leigh, and Martha Lampland. 2009. Reckoning with Standards. In Standards and Their Stories: How Quantifying, Classifying, and Formalizing Practices Shape Everyday Life. Edited by Martha Lampland and Susan Leigh Star. Ithaca: Cornell University Press, pp. 3-24.

Star, Susan Leigh, and Karen Ruhleder. 1996. Steps toward an Ecology of Infrastructure: Design and Access for Large Information Spaces. Information Systems Research 7: 111-34. [CrossRef]

Star, Susan Leigh, Geoffrey C. Bowker, and Laura J. Neumann. 1997. Transparency at Different Levels of Scale: Convergence between Information Artifacts and Social Worlds. University of Illinois, Urbana-Champaign. Available online: https://www.ics.uci.edu/ \{\}gbowker/converge.html (accessed on 25 November 2019).

Stoa, Ryan B. 2015. Droughts, Floods, and Wildfires: Paleo Perspectives on Disaster Law in the Anthropocene. Georgetown International Environmental Law Review 27: 393-446.

Stone, Christopher D. 1972. Should Trees Have Standing?-Towards Legal Rights for Natural Objects. Southern California Law Review 45: 450-501.

Swyngedouw, Erik. 2010. Apocalypse Forever? Theory, Culture E Society 27: 213-32. [CrossRef]

Taylor, Bron. 2001a. Earth and Nature-Based Spirituality (Part I): From Deep Ecology to Radical Environmentalism. Religion 31: 175-93. [CrossRef]

Taylor, Bron. 2001b. Earth and Nature-Based Spirituality (Part II): From Earth First! And Bioregionalism to Scientific Paganism and the New Age. Religion 31: 225-45. [CrossRef]

Taylor, Bron, Jen Wright, and Todd LeVasseur. 2019. Dark Green Humility: Religious, Psychological, and Affective Attributes of Proenvironmental Behaviors. Journal of Environmental Studies and Sciences. [CrossRef]

Temper, Leah, Mariana Walter, Iokiñe Rodriguez, Ashish Kothari, and Ethemcan Turhan. 2018. A Perspective on Radical Transformations to Sustainability: Resistances, Movements and Alternatives. Sustainability Science 13: 747-64. [CrossRef]

Tengö, Maria, Eduardo S. Brondizio, Thomas Elmqvist, Pernilla Malmer, and Marja Spierenburg. 2014. Connecting Diverse Knowledge Systems for Enhanced Ecosystem Governance: The Multiple Evidence Base Approach. AMBIO 43: 579-91. [CrossRef]

Todd, Zoe. 2015. Indigenizing the Anthropocene. In Art in the Anthropocene: Encounters Among Aesthetics, Politics, Environments and Epistemologies. Edited by Heather Davis and Etienne Turpin. London: Open Humanities Press, pp. 241-54. Available online: http://openhumanitiespress.org/books/art-in-the-anthropocene (accessed on 15 August 2019).

UNEP. 2017. The Emissions Gap Report 2017: A UN Environment Synthesis Report. Nairobi: United Nations Environment Programme, Available online: http://edepot.wur.nl/426310 (accessed on 20 April 2019).

Valencia Sáiz, Angel. 2005. Globalisation, Cosmopolitanism and Ecological Citizenship. Environmental Politics 14: 163-78. [CrossRef]

Van Steenbergen, Bart. 1994. Towards a Global Ecological Citizen. In The Condition of Citizenship. Edited by Bart van Steenbergen. Politics and Culture. London and Thousand Oaks: Sage, pp. 141-52.

(C) 2020 by the authors. Licensee MDPI, Basel, Switzerland. This article is an open access article distributed under the terms and conditions of the Creative Commons Attribution (CC BY) license (http://creativecommons.org/licenses/by/4.0/). 